\title{
Thoughts on Construction of Conceptual Framework of Financial Accounting in China
}

\author{
Xiling Dai \\ School of Business Administration, Shenyang University, Shenyang 110044, China \\ E-mail: sydxdxl@163.com
}

Received: January 25, 2011 Accepted: February 18, $2011 \quad$ doi:10.5539/ijbm.v6n4p237

\begin{abstract}
In order to adapt to changes of economic environment, the accounting profession of China urges to build a conceptual framework of Chinese financial accounting. Starting from the connotations and effects of conceptual framework of financial accounting, this paper analyzes the current researches on conceptual framework of Chinese financial accounting, presenting suggestions for constructing the conceptual framework of Chinese financial accounting from four aspects: basic principles, basic relationships, levels and contents, construction institute and the name.
\end{abstract}

Keywords: Financial accounting, Conceptual framework, Accounting standards, Construction

\section{An introduction to conceptual framework of financial accounting}

With the rapid development of global economy, lots of new things appear in economic life and cause some new problems to accounting practices. In order to settle the disagreements in accounting procedures and treatment methods concerning these new things, it is widely acknowledged by world accounting professions that a set of conceptual framework structural system of financial accounting will be necessary, which can be used to guide the building of accounting standards and the treatments of accounting practices, maintaining the consistency of accounting treatments and the sound theoretical basis. The study of constructing the conceptual framework of financial accounting thus comes into being.

\subsection{The connotation of conceptual framework of financial accounting}

The term of conceptual framework of financial accounting was firstly presented in The Conceptual Framework of Financial Accounting, Elements of Financial Reports, and Assessment, The Tentative Agreement on Objectives of Corporate Financial Statements, and The Scope and Meanings of Conceptual Framework published by U. S. Financial Accounting Standard Board on 2ed, Dec. 1976. The conceptual framework of financial accounting refers to a logically consistent system composed of mutually connected objectives and basic concepts. The system can guide to consistent accounting standards and set rules for the nature, effects, and limitations of financial accounting and statements.

\subsection{The Effects of conceptual framework of financial accounting}

The effects of conceptual framework of financial accounting mainly include these points as follow:

Firstly, keep the consistency of relevant documents of accounting standards and internal logics, decrease the contradictions and conflicts between relevant documents of different accounting standards and laws, limit different treatments and procedures for same transactions in practice, and improve the standardization, acceptance, and practical effect of accounting standards.

Secondly, enhance the usefulness of financial statements, and help users of financial statements or interest groups to understand the purposes, natures, and limits of information from financial statements, and make the right judgments and business decisions.

Thirdly, give guidance for the formulation of accounting standards and the solution of vital accounting problems, and also exclude personal preferences in the process of making accounting standards, and confronting political pressures from different interests groups.

Fourthly, help to further develop modern accounting theories and update the views. By studying the conceptual 
framework of financial accounting, we can not only completely confirm the practical and reasonable part in traditional accounting theories, but also reflect the latest fruits of accounting theories in time, in the circumstance of changing social economic environment, continuously promoting the deeper development of accounting theories.

\section{Current studies of conceptual framework of financial accounting in China}

Since the $80 \mathrm{~s}$ at $20^{\text {th }}$ century China has started studies of conceptual framework of financial accounting. In Nov. 1992, China introduced international accounting practices and referenced the conceptual framework of western financial accounting. Based on national situation at that time, China published Corporate Accounting Standards

----- Basic Standards. The Basic Standards was a comprehensive summary of Chinese accounting theories after the reform and opening. At that time, it was named as the semi-conceptual framework of Chinese financial accounting. It has generated vital effects on promoting Chinese accounting reform and improving the level of accounting theories.

However, the Basic Standards is not real conceptual framework of financial accounting, after all. It can not replace the conceptual framework of financial accounting by all means. The Basic Standards plays its role merely as a component of accounting standards, which also retains some traces of planned economy. With passage of time and changes of accounting environment, people's studies of accounting theories are deepening. The Basic Standards, as the semi-conceptual framework of financial accounting, displays its initial defects gradually. These defects lower the guiding effect of Basic Standards to constituting specific standards. Specifically, these defects are mainly reflected in following aspects: First, the qualitative characteristics of accounting information are not leveled and do not covered by constraints. Second, there is no detailed regulation on the disclosure of financial statements. Third, the revised version does not address some important items, such as the presentation of financial statements, the rules for composing financial statements, the definition of consolidated financial statements, the relationship of individual financial statements and consolidated financial statements. Therefore, some parts of Basic Standards do not match current accounting reform. It can not play the role of conceptual framework of financial accounting.

In 2003, China's Ministry of Finance completed a major restructuring of the Accounting Standards Committee and established a new working mechanism, which provides: the professional committee of accounting theory is responsible for studying the conceptual framework of financial accounting. It established the base for drafting the conceptual framework of financial accounting in China.

On $15^{\text {th }}$, Feb. 2006, the Ministry of Finance issued a complete accounting standards system consisted of one basic standard and 38 specific standards. Here, specific standards are based on the basic standard. The basic standard is at the highest position in Chinese accounting standards system. It declares that the construction of Chinese accounting standards system has entered into a rapidly-development stage. However, although the basic standard and the conceptual framework of financial accounting have similarities in the construction of guiding standards, the two of them have significant differences in contents, functions, natures, and forms. In other words, the basic standard can not be taken as the conceptual framework of financial accounting. Therefore, till today the conceptual framework of financial accounting has not been established in China.

Since the WTO entry, China has accelerated the process of internationalization. However, in the field of accounting system, because of the lack of a real conceptual framework of financial accounting, the development of accounting suffers from serious barriers. Thus, it is imperative to build and improve a conceptual framework of financial accounting that is right for Chinese situations, based on specific accounting practices and experiences.

By researching other countries' conceptual frameworks of financial accounting, we can conclude that: If there is not a relatively perfect conceptual framework of financial accounting, there will be no a set of highly-qualified accounting standards; If there is no or only a rough conceptual framework of financial accounting, there will be cost more for the construction of standards. Judging from the process of constructing the accounting standards in China, huge construction costs and implementation costs have been produced though they could not be testified in practice. Therefore, it is meaningless for us discussing whether a conceptual framework of financial accounting is necessary or not. At present, what we should think about is how to construct China's conceptual framework of financial accounting and use it to guide the development and implementation of specific standards.

\section{Some suggestions for constructing China's conceptual framework of financial accounting}

\subsection{Basic principles}

We should follow these basic principles as we construct the conceptual framework of financial accounting in 
China:

The first is the principle of relative stability. The conceptual framework of financial accounting is a regulatory document. It should be stable as much as possible, avoiding frequent modification and change. However, a good conceptual framework of financial accounting should change along with the continuous development of economy and changes of economic environment. Therefore, the conceptual framework of financial accounting should be foreseeable, confirming its stability by mastering the objective environment of accounting at present and in the future.

The second is the principle of consistency. As we construct the conceptual framework of financial accounting, we must be consistent in logics and words, insuring the integrity of whole conceptual framework.

The third is the principle of inheritance. We should not completely get rid of traditional accounting theories but absorb the positive parts, making the past serve the present.

The fourth is the principle of neutrality. As we construct the conceptual framework of financial accounting, we should strive to remain neutral and not favor any interest group.

The fifth is the principle of internationalization. The internationalization of accounting standards is a necessary condition for economic globalization. In order to adapt China's economy with the world economy, we should pursue for internationalization and improve the comparability of accounting information as we construct the conceptual framework of financial accounting. However, internationalization does not rule out the nationalization. In constructing the conceptual framework of financial accounting, we should fully consider China's real conditions and reflect the characteristics of China.

The sixth is the principle of system and integrity. In constructing the conceptual framework of financial accounting, we should hold a general idea as for what conceptual elements included, how many levels, and how to make classification. By this way, we can ensure that the contents of conceptual framework are systematic, comprehensive, and complete as much as possible.

\subsection{Basic relationships}

We should properly deal with these basic relationships as we construct the conceptual framework of financial accounting in China:

The first is to deal with the relationship of Chinese characteristics and internationalization. In constructing the conceptual framework of financial accounting in China, we should fully consider the uniqueness of Chinese accounting environment, pursue international accounting coordination actively, and finally achieve the ultimate goal of accounting internationalization, together with other countries' accounting fields.

The second is to deal with the relationship of conceptual framework of financial accounting and accounting theoretical system. The accounting theoretical system aims at explaining and predicting practices of accounting, but the conceptual framework of financial accounting reflecting the basic concepts for financial accounting, especially for financial statements, and their internal and consistent connections. To build the regular connection is to keep in improving the accounting standards and financial statements. Therefore, in constructing the conceptual framework of financial accounting, we should emphasize on reasoning and experiences, making it an integrated and consistent knowledge system.

The third is to deal with the relationship of conceptual framework of financial accounting and specific accounting standards or corporate accounting institutions. The conceptual framework of financial accounting does not include specific accounting procedures and disclosure system for describing trading business or particular affairs. It just offers guidance for setting specific standards. However, specific accounting standards or corporate accounting institutions are at the second level of Chinese current accounting standards system. They are not in the scope of accounting theoretical system. In addition, the procedures of constructing the conceptual framework of financial accounting should be guaranteed by authority and wide recognition.

\subsection{Levels and contents}

The conceptual framework of financial accounting is an artificial system. Therefore, in constructing the conceptual framework of financial accounting, we should make it cover all child-systems and be complete. Based on the fruits of western studies and China's practical accounting environment, by means of following the basic principles and requirements above, the author agrees that the conceptual framework of financial accounting in China should include the following levels:

The first level mainly includes three parts: goals of accounting, objectives of accounting, and accounting assumptions. They are all under the influences of environment. Goals of accounting reflect the users' subjective 
intentions, subject to the subjective environment of financial accounting. Objectives of accounting are from objective environment of financial accounting. Accounting assumptions are based on objective environment. The three of them are mutually affected and hold equal positions. Therefore, the three parts form the first level of conceptual framework of financial accounting.

The second level mainly includes three parts: accounting elements, quality characteristics of accounting information, and general principles of accounting calculation. Constrained by accounting assumptions, considering goals of accounting, objectives of accounting are transformed into accounting elements. In order to achieve goals of accounting and ensure the usefulness of accounting information, accounting information should reach certain level of qualities. In order to establish and assess accounting elements rightly and provide useful accounting information, accounting calculation must adhere to general principles.

The third level mainly includes four parts: establishing, calculating, recording, and reporting the accounting elements. According to the concepts and standards of establishment and calculation, and the definition and traits of accounting elements, all past transactions and events should be calculated and recorded as different accounting elements and accounts. By means of financial statements, make them be useful accounting information, and provide them to users of accounting information. This series of accounting procedures constitute the final level of conceptual framework of financial accounting.

In summary, the author divides the conceptual framework of Chinese financial accounting into six parts: (1) Introduction: mainly includes the purposes, context of application and scope, goals of financial accounting, the nature, effects, and limits of financial accounting and statements, etc. (2) Basic assumptions of financial accounting and principles of accounting calculation. (3) Definitions of financial accounting elements. (4) Quality characteristics of financial accounting information. (5) Establishment, calculation, and record of financial accounting elements. (6) Financial statements.

\subsection{The construction institute and the name}

In western countries, it is the financial accounting standards board that is responsible for the construction and release of conceptual framework of financial accounting. But in China, it is the Ministry of Finance that sets up and issues the accounting standards. Generally speaking, the conceptual framework of financial accounting and the accounting standards should be constructed and issued by the same institution. Therefore, in author's opinion, in China it is the Ministry of Finance that should construct and issue the conceptual framework of financial accounting.

As for the name issue of conceptual framework of financial accounting in China, the author thinks that its Chinese official name should be generally understood and accepted by most people in accounting field. Besides, it should not only reflect the relationship of the conceptual framework of financial accounting and the accounting standards, but also embody the essence of conceptual framework of financial accounting. Therefore, by referring to different names of conceptual framework of financial accounting in western countries, the author proposes that "the theoretical framework of accounting standards" or "the framework of accounting theories" can be used as the Chinese official name of conceptual framework of financial accounting.

\section{References}

Jing, Cuilian. (2007). International convergence and its apocalypse of conceptual framework of financial accounting. Journal of Chongqing Jiaotong University (Social Sciences Edition), No.6.

Li, Gaobo. (2010). A study of repairing the logic effects of conceptual framework of China's financial accounting. Journal of Yunan Finance \& Trade Institute, No.10.

Wang, Haibing. (2006). Suggestions for construction of conceptual framework of financial accounting in China. Communication of Finance and Accounting, No.3.

Wong, Jianying. (2007). The development and effects of conceptual framework for financial accounting. Journal of Shanghai Lixin University of Commerce, No.5.

Yun, Hong. (2009). Thoughts on construction of conceptual framework of financial accounting in China. On Economic Problems, No.4. 